\title{
Changing Roles: Original Cataloging by Paraprofessionals in ARL Libraries
}

\section{Deborah A. Mohr and Anita Schuneman}

The role of the paraprofessional cataloger in academic libraries is rapidly changing. The authors in this study investigated the nature of paraprofessionals' work in original cataloging activities at ARL institutions and compare their findings with those of an earlier survey. Original cataloging was defined to encompass a variety of activities including description, the creation of name and uniform title headings, subject analysis, and classification. Findings reveal that $77.1 \%$ of the cataloging department heads at the responding ARL institutions report paraprofessional involvement in one or more of these activities, with original description the most common and subject analysis the least common. Among the reasons commonly cited for such involvement were paraprofessional career development and cost savings. The respondents also noted advantages and disadvantages of paraprofessional participation in original cataloging as well as reactions they had observed among both professional and paraprofessional catalogers to this participation.

$\mathbf{T}$ I he role of the paraprofessional cataloger in academic libraries is changing at an ever-increasing rate. Both experience and a review of the literature demonstrate that paraprofessionals are taking on tasks previously performed only by professional librarians. While at one time there may have been general agreement that librarians performed the intellectual work of cataloging and paraprofessionals the routine tasks, it is no longer clear that this is where the distinction between "professional" and "paraprofessional" work lies. Although philosophical issues rarely arise on the job, catalogers and cataloging managers deal with the practical issues on a daily basis, and our interest arose from our awareness of increasing paraprofessional involvement in original cataloging. In this study, we examine the daily operations to determine what original cataloging activities are being performed by paraprofessionals.

\section{Research Questions}

We hypothesized that paraprofessionals participated widely throughout the

DEBorAh A. MOHR (mohr@smccva.lib.monroecc,edu) is Database Control Librarian, LeRoy V. Good Library, Monroe Community College, Rochester, New York. Anita Schuneman (aschunem@carbon.cudenver.edu) is Acting Coordinator of Cataloging, Services, and Special Collections, Auraria Library, University of Colorado, Denver. Manuscript received February 16, 1997; accepted for publication April 24, 1997. 
Association of Research Libraries (ARL) libraries in all areas of original cataloging, with the greatest level of involvement in original description and in literature classification and the smallest in subject analysis and in classification of nonfiction works. It was further hypothesized that comparison with past studies would reveal a continuation of the trend of increasing paraprofessional involvement in original cataloging over time.

Third, it was hypothesized that ARL cataloging department heads would most frequently cite cost savings as a reason for paraprofessional involvement in original cataloging, given the current difficult economic situation of many libraries. Finally, we projected that revision of original cataloging work would more often continue beyond the initial training period for paraprofessional catalogers than for professionals.

\section{Literature Review}

Authors of previous surveys have documented the involvement of paraprofessionals in original cataloging. Further, they have shown that paraprofessional participation has been increasing steadily at least since 1977, six years after OCLC's debut, when Braden, Hall, and Britton (1980) surveyed OCLC member libraries about their cataloging practices. They defined "original cataloging" as "cataloging without copy" and found that respondents in $16.6 \%$ of the larger libraries stated that support staff handled original cataloging either alongside professional catalogers or exclusively.

A few years later, in 1983-84, Eskoz (1990) surveyed catalog departments in 160 academic libraries chosen for "regional balance and a varied range of campus sizes and types" (p. 380). She subsequently conducted follow-up interviews with catalog department heads in 40 of the libraries in 1986 and 1987. She found that both professionals and support staff did original descriptive cataloging in $30 \%$ of the libraries in 1983-84, which increased slightly to $35 \%$ of the libraries by 1986-87. However, support staff were assigned this original cataloging in only two of the li- braries in the surveys, while no professionals were assigned this responsibility. Eskoz found similar rates of paraprofessional participation in assigning call numbers $(32.5 \%$ in $1983-84,35 \%$ in $1986-87)$ and assigning subject headings $(27.5 \%$ in $1983-84,35 \%$ in $1986-87)$.

By 1990 , Oberg et al. (1992) found that paraprofessionals regularly did original descriptive cataloging in $51 \%$ of the ARL institutions that responded to their survey. However, the percentages of ARL libraries in which paraprofessionals assigned subject headings and call numbers remained about the same ( $36 \%$ for each task), a figure similar to that found in Eskoz's second study. In Conturbia's 1991 study (1992) of cataloging of foreign-language materials, although more specific in scope, the author found similar levels of paraprofessional involvement in these tasks.

Despite differences in the populations surveyed, definitions, and methodology, these authors pointed to a general trend in cataloging that was occurring throughout the library world during the same period: the increasing delegation to paraprofessionals of tasks formerly considered professional. This trend reflected emerging thought about the proper role of the professional librarian in technical services-and in the profession in general-as managers, leaders, and innovators, less involved than previously in day-to-day operations (Veaner 1982; Bishoff 1987; Younger 1991; Rider 1996).

There were other factors that had an effect on the responsibilities of cataloging librarians and staff respectively. During this period, automation made many library tasks more routine, and in cataloging departments, the increased availability of copy for copy cataloging pushed broad implementation of copy cataloging. At the same time, copy catalogers gained experience and skills over the years (Benaud 1992), which could be used for more complex work. In addition, economic pressures pushed for the containment of costs through the delegation of tasks to the lowest levels of staff possible while maintaining an acceptable degree of quality and without harming morale (Williams 1991).

With these developments came con- 
cern for paraprofessionals in their changing roles as well. Oberg (1994, 1995; Oberg et al. 1992) led the call for equitable treatment of paraprofessionals in libraries and indicated the need to imbue paraprofessionals with the profession's traditional values as support staff play a greater role in libraries. Rider (1996) approved of the new roles for copy catalogers as a means for them to use their experience and skills appropriately, while Dyckman (1992) emphasized attention to recruitment and retention of paraprofessionals in their developing role.

Nettlefold's sociological view (1989, 523) of these trends posited that the rise of paraprofessionalism in libraries resulted from the maturing of the library profession:

Aspiring professions ... have often resisted paraprofessionalism initially, afraid of a claim on their "exclusive skill jurisdiction." ... As the aspirants have redefined and upgraded their core of knowledge and skills, confidence in their professionalism has grown. They have therefore begun to act as established professions and now foster paraprofessionalism. . . Librarians at first opposed paraprofessionalism, but as their professionalism has grown, opposition has turned to support.

Representing another sociological perspective, Harris (1992, 9-10) argued that: some of the female areas of specialization, especially cataloging, are undergoing a process of 'deprofessionalization' or 'deskilling,' .. [ which] can occur when a field loses control over its knowledge base. In the case of cataloguers, this loss of control has come about largely because of the widespread use of cataloguing networks . . . [which] not only shifts most of the inhouse cataloguing work in libraries to nonprofessional staff but . . . also alters the working patterns of the remaining professional cataloguers, [who can no longer specialize in particular subject areas.]

\section{METHODOLOGY}

We developed an original survey instrument, which was mailed in April 1995 to the heads of the main cataloging depart- ments of the 119 ARL institutions. ARL libraries served as the target population because their specialized collections meant higher rates of original cataloging than for many other academic libraries and for ease of comparison with some past studies. After two follow-up mailings, 83 respondents had returned their questionnaires for a total response rate of $69.7 \%$.

We developed our own survey instrument because none of the existing questionnaires of which we were aware dealt with all of the issues we wished to explore. As would be expected, the questionnaire from the earlier study of Braden, Hall, and Britton included questions about nowoutdated cataloging policies. The survey by Eskoz, which was closest in scope to ours, did not contain the same level of detail with regard to the reasons for paraprofessional involvement in original cataloging or the reactions of professionals. Oberg's 1990 survey focused on all library paraprofessionals, while Conturbia limited her survey to foreign language cataloging.

Methodologies differed as well among these surveys as to the libraries surveyed, survey respondents, and what followup measures were employed. Two of the 4 studies were specifically targeted at ARL libraries, although all surveyed academic libraries. All but Oberg's broader study were surveyed cataloging department heads rather than cataloging practitioners. One researcher, Eskoz, used telephone interviews as a means of follow-up.

\section{DEFINITIONS}

For the purposes of the study, "original cataloging" encompassed original bibliographic description, establishment of name and uniform title headings, subject analysis, and both nonfiction and literature classification, when any of these exceeded verification of data in existing records. This definition included tasks sometimes performed in complex copy cataloging, such as assigning subject headings to a bibliographic record that lacked them. "Revision" meant a review of the cataloging decisions made in a record, as opposed to general proofreading. 
"Professional" catalogers were defined as those who held positions that required a master's degree in library or information science. "Paraprofessional" catalogers were defined as those who held positions that did not require an M.L.S., although many paraprofessional library employees do have the degree. The definitions of all these terms were included in the appropriate survey questions so that respondents were aware of them.

The term paraprofessional was used despite its drawbacks. Benaud $(1992,84)$ notes that paraprofessional, while one of the most prevalent terms, along with support staff, for describing library workers without an M.L.S., "no longer reflects the sophisticated skills needed on the job." Oberg (1995), while acknowledging the drawbacks, finds the use of the term paraprofessional highlights comparisons with similar phenomena in fields such as law and medicine.

Definitions used in previous studies differ from the definitions used here, although not so significantly as to prevent later comparison. For example, Oberg (1992) defined "paraprofessional" to include office support and other staff activities, which were omitted from the definition here because only paraprofessional staff in cataloging departments were considered. However, the definitions of original cataloging were very similar-either "cataloging without copy" or a listing of tasks-and again support subsequent comparison among survey findings.

\section{SuRvey Findings}

Eighty-three librarians responded. The findings are reported question by question (13 questions in all). The questions covered the following topics: department size, original cataloging activities performed by paraprofessionals, what revision of original cataloging was done, reasons for paraprofessional involvement in original cataloging, reactions observed among cataloging employees to this involvement, and advantages and disadvantages of the paraprofessional involvement from the perspective of the cataloging department heads surveyed. The survey findings are reported generally in the order of the questions on the survey, with the exception of department size which is reported after the question of what original cataloging activities are performed by paraprofessionals. Immediately following the findings on each question, we have included a brief discussion of these findings in the context of other studies.

\section{Distribution of Origrnal Cataloging Activities}

Overall, 64 libraries $(77.1 \%$ of those responding) had paraprofessional employees who performed some original cataloging tasks, while 19 (22.9\%) did not. Of the 64 responding libraries where paraprofessionals were involved in original cataloging, 63 (98\%) also indicated the tasks that paraprofessional catalogers performed. The distribution of original cataloging tasks is shown in figure 1 .

\section{ORIGINAL DESCRIPTION}

Original description was the original cataloging activity most commonly performed by paraprofessionals in the responding libraries. Paraprofessional catalogers did original descriptive cataloging in 62 of the 63 libraries in which cataloging department heads responded to this question. While this result agreed with the hypothesis, the extent of the participation was astonishing; paraprofessionals do original description in nearly $100 \%$ of the libraries in which they participate in original cataloging activities.

The result is perhaps less surprising given the paraprofessionals' copy cataloging experience. Also, a wealth of documentation-including the Anglo-American Cataloguing Rules second edition; Library of Congress Rule Interpretations; guidelines; and manuals-provides a solid base for training in original descriptive cataloging.

The level of paraprofessional involvement in original descriptive work has increased notably since the survey of ARL libraries conducted in 1990. That survey found paraprofessionals were regularly assigned original descriptive cataloging in 


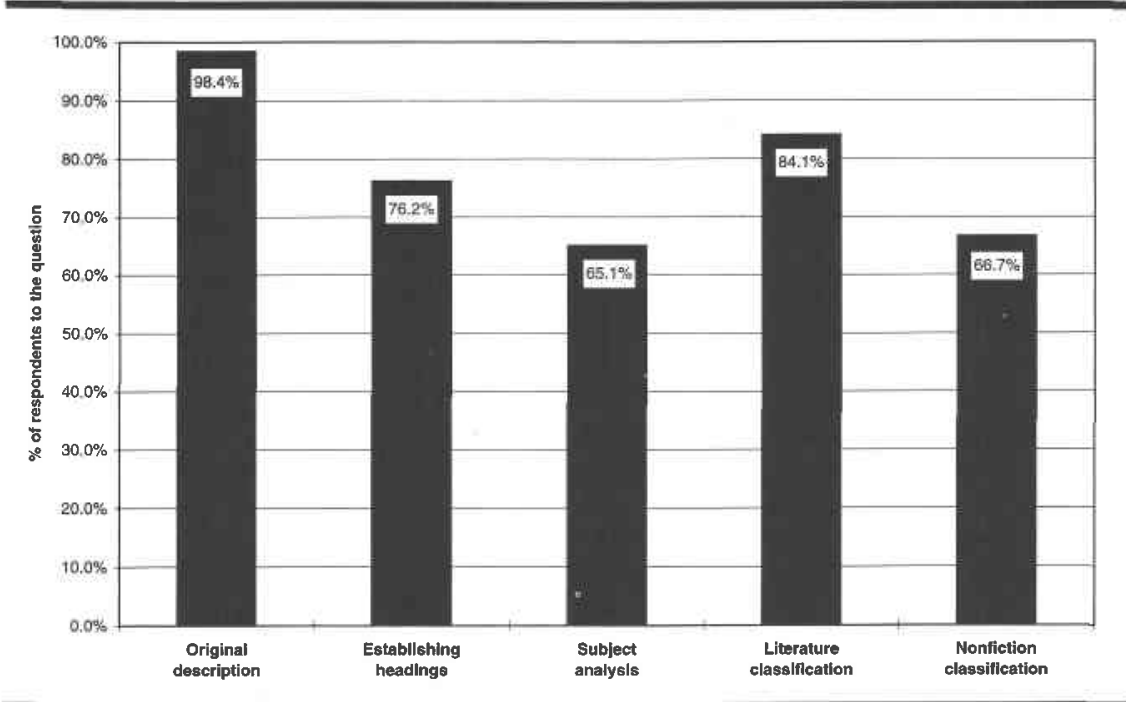

Figure 1. Distribution of Original Cataloging Tasks among Paraprofessionals.

$51 \%$ of the responding libraries (Oberg et al. 1992), versus $74.7 \%$ of all respondents to the present survey. In the present study, "regular" participation was not specified, but even with this difference in definitions, there appears to be widespread acceptance of paraprofessional participation in original descriptive cataloging in ARL libraries.

\section{Classification}

Paraprofessionals did original literature classification in $53(84.1 \%)$ and original nonfiction classification in $42(66.7 \%)$ of the 63 libraries in which paraprofessionals were involved in original cataloging. The first finding reflects long-standing practice, as described by Foster $(1987,96)$ ten years ago: "In at least a few libraries nonprofessionals are being assigned certain original cataloging operations. . . . Nonprofessional cataloging of fiction books has proven especially successful." This success rests in part on the relatively similar classification schemes and common use of standard tables for classifying literature.

Although authors of previous studies have not differentiated between literature and nonfiction classification, no study shows as high a percentage of paraprofessional involvement in classification in general as the present survey. The rates of participation in the studies by Eskoz, Oberg et al., and Conturbia ranged from $32.5 \%$ to $37.5 \%$ of responding libraries. Even the lower rate of involvement for original nonfiction classification in the present survey, $49.4 \%$ of all respondents, represents a $13.4 \%$ increase since the 1990 study by Oberg et al., although again definitions of participation differ somewhat.

The trend might be attributed to increasing acceptance of paraprofessionals' contributions and abilities in this area as well as to time and financial pressures. In addition, Rider $(1996,29)$ predicts that "subject headings and classification numbers will continue to be assigned by greater numbers of staff with appropriate training because the information can often be adapted quickly from other online sources."

\section{SUBJECT ANALYSIS}

Consistent with the hypothesis, 41 $(65.1 \%)$ of the 63 libraries in which para- 
professionals are involved in original cataloging have them perform original subject analysis. This is, however, close to the number of libraries (42) in which paraprofessionals do original nonfiction classification. This finding may reflect the fact that subject analysis and nonfiction classification are the two cataloging tasks most often cited as professional activities that require an M.L.S. (Benaud 1992). From our own experience, these areas are also less codified and documented than the others and require the most creative application of the sketchier rules that do exist.

Comparisons with findings from past studies show a substantial increase in the rate of paraprofessional involvement in original subject analysis, a result similar to that found in the area of original classification. In the current study, the rate was $49.4 \%$ of all respondents; in earlier studies, it ranged from $36 \%$ of responding ARL libraries in Oberg et al. (1992) to $30 \%$ for foreign-language materials in Conturbia (1992). The trend might be due to increasing acceptance of paraprofessionals' contributions and abilities in this area, economic and time pressures, and better documentation and rationalization of subject analysis practices over the past few years.

\section{ESTABLISHMENT OF NAME AND UNIFORM TITLE HEADINGS}

Cataloging department heads indicated that paraprofessional catalogers establish some name and uniform title headings in $48(76.2 \%)$ of the 63 libraries in which paraprofessionals do some original cataloging, which is $57.8 \%$ of all responding libraries. Authors of past studies did not distinguish between this activity and original description in general, so there are no grounds for comparison. As shown in figure 1 , this task is the third most commonly performed by paraprofessionals in the responding libraries, after original description and literature classification and before original nonfiction classification and subject analysis.

Heading establishment and authority record encoding are well documented, which may aid in training along with paraprofessionals' exposure to headings and authority work in copy cataloging. In our experience, a copy cataloger was the biggest contributor of name and series headings to the NACO (Name Authority Cooperative) project in the library in which we formerly worked, showing the potential importance of paraprofessional contributions in this area.

\section{Department Size and Composition}

We sought to identify what constitutes a typical configuration for an ARL cataloging department in which paraprofessionals do some original cataloging. Questionnaire respondents gave the numbers of paraprofessional and professional positions in their cataloging departments in full-time equivalents (FTEs). Total department sizes ranged from 4 to 124 FTEs in the libraries in which paraprofessionals performed some original cataloging, with an average of 24.9 FTEs per department. In libraries where paraprofessionals did no original cataloging, department sizes ranged from 7 to 657 FTEs, with an average of 53.9 FTEs.

The wide range in size of the second group is due to the Library of Congress (LC), which is an exceptional library because of its FTE count of 657, which raises the average size by 33.2 FTE. For that reason, median department size might represent a more meaningful basis for comparison between these two groups of libraries. For libraries in which paraprofessionals participated in original cataloging activities, median department size was 23 FTEs, versus 19 FTEs for the libraries in which paraprofessionals did no original cataloging. Paraprofessional involvement in original cataloging thus appears slightly more likely with greater department size (with the exception of LC), perhaps because of the larger pools of skills upon which to draw as well as the potentially greater quantities of materials that require original cataloging.

Cataloging departments for both groups of libraries generally had more paraprofessional than professional positions. Among libraries in which parapro- 
fessionals performed some original cataloging, the overall ratio of paraprofessional cataloging positions to professional cataloging positions in FTEs was 1.79 to 1 . For the other group, the average ratio was 1 paraprofessional to 1.46 professionals, although this reversal disappears if LC is eliminated, which changed the overall ratio to 1.4 paraprofessional FTEs to 1 professional FTE. Departments in which paraprofessionals participated in original cataloging had, on average, about 1.25 times as many paraprofessional FTEs for each professional FTE as the departments in which paraprofessionals did no original cataloging.

This difference in configuration makes sense. With a higher ratio of professional cataloging positions to paraprofessional positions, the need for paraprofessional involvement in original cataloging is mini$\mathrm{mal}$, with the larger number of professionals as well as the large amount of cataloging copy available to all but the most specialized libraries. In larger departments with a lower ratio of professional to paraprofessional positions, more pressure occurs for paraprofessionals to perform original cataloging. Paraprofessional participation in original cataloging can both assist in getting the original cataloging done when there are fewer professional catalogers, who are also apt to be required to spend more time on activities other than title-by-title cataloging, and keep the paraprofessionals supplied with work. Later questions in the survey identify other reasons for paraprofessional participation in original cataloging activities.

\section{CoMparison of REvision RATES}

Revision of original cataloging work is one method of quality control. Respondents from ARL libraries in which paraprofessionals did some original cataloging indicated whether or not paraprofessionals as a group and professionals as a group were generally revised in their original cataloging activities after training. If the answer was yes, respondents indicated whether professional catalogers, paraprofessional catalogers, or both did the revising. "Revision" was defined as a review of the cataloging decisions made in a bibliographic record, rather than mere proofreading.

Responses were nearly evenly split between departments in which paraprofessionals continued to undergo revision of their original cataloging even after full training: in $33(55 \%)$ of the responses revision continued after training, and in 27 $(45 \%)$ revision ceased with training. For professional catalogers, however, continuing revision of original cataloging occurred much less often, taking place in only $17(27.9 \%)$ of the responding libraries, as opposed to $44(72.1 \%)$ of libraries in which professional catalogers worked with no revision beyond the training period. Although small in scale, authors of a survey done in 1988-89 of eleven ARL libraries learned that "support staff are more likely than professionals to be evaluated on the basis of statistics kept on material processed or work completed or on the basis of 'qualitative' checks of their output" (Estabrook, Mason, and Suelflow 1993, 239).

In most cases, if continuing revision of the work of either paraprofessionals or professionals was done, professional catalogers performed it (paraprofessionals: 27 , or $81.8 \%$ of the respondents to this question; professionals: 14 , or $87.5 \%$ ). Nowhere did only paraprofessionals revise original cataloging, although both paraprofessional and professional staff did so for paraprofessionals in $6(18.1 \%)$ of the responding libraries and for professionals in $2(12.5 \%)$. This finding lends some support to Benaud's observation $(1992,86)$ that "experienced catalogers, professional or not, act as 'resource' persons and train new catalogers. As a result, it is often the case that paraprofessional catalogers train [professional catalogers] and revise [their] work." The findings of this study lend only partial support in that it does not appear to be often that paraprofessionals revise the work of professionals ( 2 , or $12.5 \%$ of the libraries). Our finding also indicates that while acceptance and even advocacy of paraprofessional involvement in original cataloging might be widespread in ARL libraries, there still exists one line of demarcation 


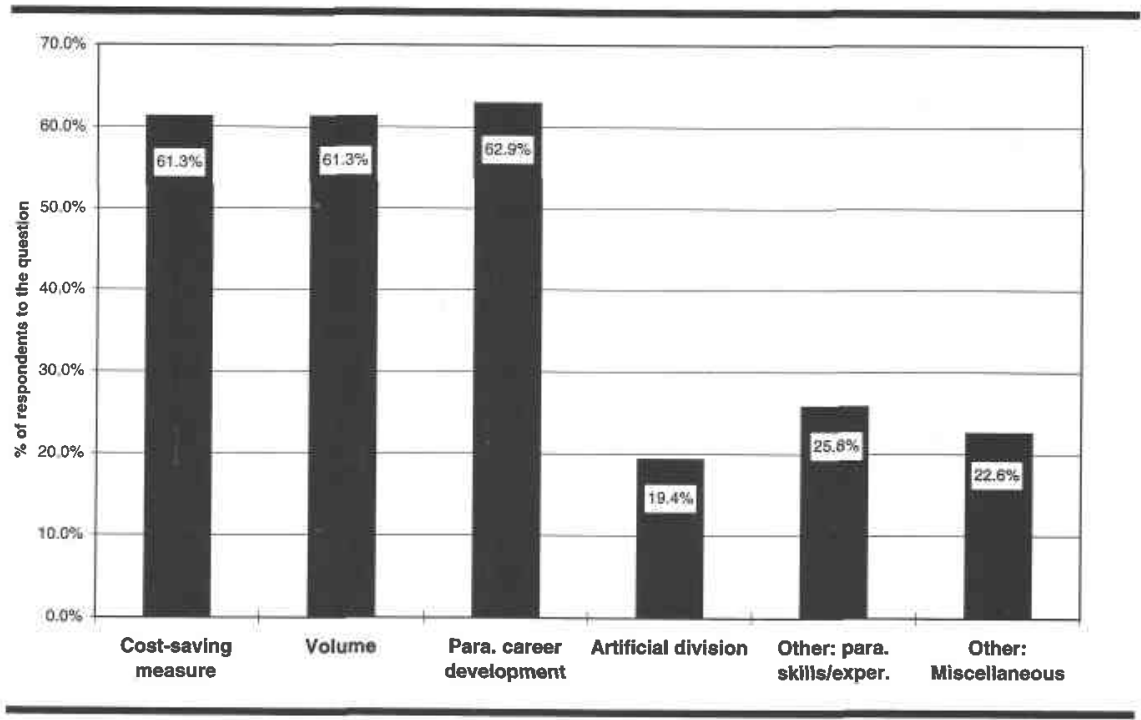

Figure 2. Reasons for Involving Paraprofessionals in Original Cataloging.

between "paraprofessional" and "professional" roles in many cases.

\section{REASONS UNDERLYING \\ Paraprofessional InVolvement}

Most questionnaire respondents indicated one or more reasons why paraprofessional employees did or did not do original cataloging in their libraries. These were not mutually exclusive. Almost all $(62$, or $96.9 \%)$ of the respondents from libraries in which paraprofessionals performed original cataloging tasks answered this multiple-choice question. The results are presented in figure 2 . The respondents most frequently chose "career development for the paraprofessional employees" as a reason $(39$, or $62.9 \%$ of those who answered the question), which does not support the hypothesis that cost savings would be the most commonly cited reason.

It is heartening that so many of the cataloging department heads who responded were concerned with the growth and development of their paraprofessional staff. This concern echoes discussion in the literature (Oberg 1994, 1995; Rider 1996). As Rider (1996, 29) notes, paraprofessionals "should have more opportunities for advancement and individual recognition, and continue to play more visible roles within the library profession." Indeed, this finding suggests that paraprofessional involvement in original cataloging benefits both the libraries and the paraprofessional catalogers.

Concerns for cost and getting the original cataloging done followed closely as cited reasons for involving paraprofessionals in original cataloging. "Cost-saving measure" or "original cataloging volume too great for professional employees alone" were cited by 38 (61.3\%) of the respondents. And nearly half the respondents $(27$, or $43.7 \%$ ) selected both cost savings and volume as reasons. In some cases, the cost savings may have arisen from lower salaries for paraprofessionals, raising an equity issue, but Williams (1991, 33-34) has also noted that "the contribution of librarians to technical services operations is relatively expensive. While their salaries may not be high, the amount of time that librarians are asked to spend on [activities outside their departments] means that much of their time is spent outside the units in which they work." In many academic libraries, para- 
professionals may spend much more of their time actually cataloging than do professional catalogers. This has been our own experience as catalogers.

Only $12(19.4 \%)$ cited "the division between professional and paraprofessional cataloging is artificial" as a reason, and none as the sole reason. For the most part, cataloging department heads focused on the more practical issues of career development of paraprofessional staff members and the exigencies of budgets and workloads.

\section{Other Reasons}

Half the respondents from the 64 libraries in which paraprofessionals did some original cataloging specified additional reasons. $16(25.8 \%)$ mentioned the paraprofessionals' experience and general qualifications, their subject, language, and format expertise, and the appropriateness of delegating the less complex, more routine aspects of original cataloging to paraprofessionals. Other reasons, cited less frequently, included institutional policies that professional librarians should not catalog $(6.3 \%$ of those who gave other reasons), the difficulty of recruiting a sufficient quantity or quality of professional catalogers $(6.3 \%)$, the demand for professionals in other areas of the libraries $(3.1 \%)$, and the historical lack of division in some libraries between professional and paraprofessional cataloging tasks $(3.1 \%)$. These other reasons also focused largely on the practical concern of getting the work done.

Among respondents from libraries in which paraprofessionals did no original cataloging, $17(89.5 \%)$ gave one or more reasons why not. Again, multiple reasons were mentioned. These respondents most often selected "original cataloging should be a professional activity" (9, or $52.9 \%$ of respondents to this question) as a reason. While the choice of this reason did not indicate whether the opinion was the respondents' own or an institutional policy, in effect it served as the latter. The question of what constitutes professional work in cataloging was as much a practical issue as it was a philosophical one for this group of respondents.

"Civil service rules, union contract, or other such restrictions" ran a close second, selected by $8(47.1 \%)$. Only 3 $(17.6 \%)$ indicated "available paraprofessional employees [are] inexperienced or otherwise unsuited," and none gave this as the sole reason. No one chose "[a] lack of professional employees to train and revise the paraprofessionals" as a reason why the paraprofessionals did no original cataloging.

Three $(17.6 \%)$ of the respondents to this question specified other reasons why paraprofessionals did not participate in original cataloging in their libraries. These other reasons included having sufficient professional catalogers to do all the original cataloging or, conversely, enough copy cataloging to keep the paraprofessional catalogers occupied; the value of professional activities in enriching original cataloging abilities; and "tradition-difficult to break resistance from both professionals and paraprofessionals." As more libraries have involved paraprofessionals in more aspects of original cataloging, however, this tradition has become less entrenched and will continue to do so. Resistance from paraprofessionals who would prefer not to do original cataloging without an increase in pay has merit, and this inequity should be addressed by the profession.

\section{Reactions to Paraprofessional INVOLVEMENT}

The 64 cataloging department heads who responded to the survey that paraprofessionals in their libraries participated in original cataloging were asked in an openended question to describe briefly any reactions they had observed among either paraprofessional or professional catalogers to this development. 39 (73.6\% of the respondents to this question) reported they observed positive reactions among paraprofessionals, while $7(13.2 \%)$ observed negative reactions. In reporting reactions among the professionals, 30 $(58.8 \%)$ pointed to positive reactions, and $14(27.4 \%)$ found negative reactions. 7 respondents reported mixed reactions 
from both paraprofessional (13.2\%) and professional (13.7\%) catalogers.

\section{REACTIONS OF PARAPROFESSIONALS}

On the positive side, paraprofessionals were observed to "enjoy" original cataloging and to find it "more difficult, challenging, and job rewarding." The mixed reactions reported usually included both themes of resentment and enjoyment, which is understandable in situations where paraprofessionals received additional training and responsibility without attendant increases in compensation and status.

According to the department heads, a recurring negative reaction among paraprofessionals was "resentment of doing professional work for lower pay" than the professionals. Many paraprofessionals were long-term employees who had absorbed other formerly professional duties over the years. These sources of resentment have been discussed by Oberg (1995, 1994). Williams (1991, 39) states "support staff members who learn new skills will have to be paid more, and, if these employees are to be given managerial slots, mechanisms must be developed to allow them to sit with librarians in policy making sessions when it is appropriate and to pay them at levels commensurate with their responsibilities."

\section{Reactions among Professionals}

Many department heads observed positive reactions among professional catalogers. Professionals in some libraries welcomed help with the routine aspects of original cataloging and in others appreciated the paraprofessionals' expertise in particular languages, formats, or subject areas. This range of reactions is to be expected as the profession's focus continues to shift from day-to-day operations to responsibility for management, leadership, and innovation.

Other respondents to this question stated that the professional catalogers in libraries in which paraprofessional catalogers participated in original cataloging were sometimes "upset at seeing original cataloging 'demeaned' as inappropriate for professional attention." They complained that "administrators don't understand or value the work of catalogers." Paiste and Mullins (1990) offer some suggestions for job enrichment for professional catalogers that might indirectly reduce some of these tensions. Their lengthy list is varied but with a common theme: the activities do not focus on cataloging individual works. Their suggested activities call for more involvement in the overall work of the cataloging department in areas such as planning, goal setting, establishing standards, hiring and training new library assistants and catalogers, supervising department work units, consulting with those outside the department, instructing library employees and users in effective use of the catalog, working on assignments outside of cataloging, managing cataloging projects, and developing specialized knowledge in handling particular subjects or types of materials.

\section{Advantages and Disadvantages of Paraprofessional InVolvement}

For the 64 libraries in which paraprofessionals participated in original cataloging activities, $62(96.9 \%)$ listed the advantages they saw in involving paraprofessionals in this way in response to an openended question. Many of the advantages mentioned appeared to be elaborations of the reasons for involving paraprofessionals in original cataloging in the first place.

\section{Advantages}

Respondents emphasized the advantages both to paraprofessionals and to the cataloging departments and libraries. The main advantage to professional catalogers was that involving paraprofessionals in original cataloging freed the professionals' time for more complex cataloging, for management and problem-solving, for professional activities, and for duties in other areas of the library, such as bibliographic instruction. A few respondents also mentioned better morale and job satisfaction among professional catalogersperhaps because they felt better able to 
fulfill truly professional roles-as well as among paraprofessional catalogers.

For the most part, however, respondents focused on the advantages to the paraprofessional catalogers of participating in original cataloging activities. According to respondents, paraprofessionals gained job satisfaction and better morale from applying their experience and their language, format, and subject skills to what the paraprofessionals perceived as the challenging, varied, and interesting tasks of original cataloging. The training and experience in original cataloging enhanced their understanding of cataloging issues and even their copy cataloging work. Some earned tangible rewards of promotions or pay increases, while others experienced intangible gratification such as the "reward of contributing to [a] national database so that other catalogers can use their work."

Increased job satisfaction led, in turn, according to the respondents, to a better retention rate for paraprofessional catalogers. One pragmatic department head also commented that "technological changes are eliminating the more routine technical services activities. Unless paraprofessionals are performing more advance[d] activities, their jobs will be eliminated." As Rider $(1996,29)$ has noted, "the growing trend to accept a higher percentage of cataloging copy with minimal editing" will provide opportunities for paraprofessionals to perform more complex duties.

\section{AdVANTAGES FOR THE LIBRARY}

Respondents also identified many benefits of having paraprofessionals contribute original cataloging. Chief among these were greater productivity and the reduction of backlogs, in part because paraprofessionals generally had more time for cataloging than did professionals. In addition, Benemann $(1993,19)$ has asserted that "the more complex you make a cataloger's task, the more productive he or she becomes." In several cases the paraprofessionals' original cataloging work filled gaps left by dwindling personnel budgets or by the difficulty of recruiting qualified professional catalogers. Materials were made available more quickly, and access was provided to some materials that would otherwise not have received full cataloging treatment, thereby benefiting library users.

Paraprofessional involvement in original cataloging improved efficiency, which, as one respondent noted, "requires that work be done at the lowest level that is capable of doing it well." Paraprofessional participation also increased the cost-effectiveness of original cataloging and "allow[ed] the librar[ies] to concentrate resources on other things."

Other advantages to the cataloging departments were the sense of teamwork and partnership that resulted, the increased contributions of paraprofessionals to departmental decision making, and professional development for both paraprofessionals (as catalogers) and professionals (as supervisors). One respondent found paraprofessional participation in original cataloging mirrored the situation in other library departments, where paraprofessionals handled most of the daily operational tasks.

Even in libraries where paraprofessionals did no original cataloging, 17 $(89.5 \%)$ of those respondents answered the question, although for their libraries the advantages are hypothetical. 14 $(82.3 \%)$ saw the same potential advantages as reported by cataloging department heads from libraries where paraprofessionals did participate in original cataloging. Three respondents (17.6\%) either saw no advantages or found the question irrelevant in their situations.

\section{DisADVANTAGES}

The cataloging department heads from 38 (59.4\%) of the libraries in which paraprofessionals did some original cataloging described the disadvantages of paraprofessional involvement in original cataloging. They most commonly mentioned the time and personnel resources needed to train and supervise the paraprofessionals and to provide ongoing quality control of their original cataloging work. As one respondent pointed out, "Total person-hours can 
be more per title (although since some of the hours are from lower-paid paras, the cost is less)." The time needed for training was a particular drawback if the library's paraprofessional cataloging staff underwent high turnover. Training and supervision required time from the professional catalogers, who did not always like or feel prepared for a management role.

The respondents' other major concern was to avoid exploiting the paraprofessionals who did original cataloging, reflecting the reactions some had observed among the paraprofessional catalogers themselves. Many department heads mentioned the issue of equity for paraprofessional and professional catalogers in terms of both job descriptions and levels of compensation. Some commented that this had not been an issue in their own libraries, but "in some situations some paraprofessionals might [feel] that their positions should be [up]graded and their salaries increased" when they began assuming original cataloging tasks. Professional catalogers, according to the respondents, also reacted negatively at times to the "role blurring" that occurred and feared the downgrading of their own role in cataloging.

Respondents to this question mentioned several other disadvantages or concerns. The educational backgrounds of the paraprofessional catalogers varied from that of professionals, particularly in that some paraprofessionals did not have the foreign-language or subject knowledge needed for original cataloging. This opinion was not unanimous, however; one respondent articulated that the best use of the talents of each employee was critical and that many of the paraprofessionals in that library have advanced degrees, language expertise, and specialized subject knowledge. Some department heads also saw the paraprofessionals' lack of the theoretical background gained from formal study of cataloging principles (usually gained in an M.L.S. program) as well as their lack of involvement in professional activities and lack of awareness of cataloging issues and trends as another factor in the amount of training required. Several respondents reported the difficulty that paraprofessionals faced in switching back and forth between original cataloging and copy cataloging policies and procedures: "in copy cataloging they check [so] much of the bib record that they defeat the purpose of copy cataloging." Another drawback was the inflexibility of civil service rules or union contracts as to the duties paraprofessionals could perform; while department heads in some libraries might have liked to offer paraprofessionals more opportunities to do original catalogingpresumably with appropriate compensation-this was not always possible.

Of the cataloging department heads from the 19 libraries in which paraprofessionals did not perform any original cataloging activities, 14 (73.7\%) described the potential disadvantages of having paraprofessionals do original cataloging. This group raised many of the same points as the other group of respondents, but some additional concerns reflected the reasons this group had indicated for not involving paraprofessionals in original cataloging work. Some stated that original cataloging should be a professional task, that having paraprofessionals participate would not be cost-effective, or that "cataloging productivity [might] suffer." One respondent noted that the original catalogers in his or her department could not agree among themselves about which duties the paraprofessionals should perform. In a related concern, other department heads were afraid of possible negative effects on the professionals' morale from the blurring of the line between professional and paraprofessional tasks and the potential downgrading of the profession.

\section{CONCLUSION}

The results of this survey highlight continuing changes in assignment of original cataloging responsibilities. Paraprofessionals are assigned some original cataloging tasks in the majority of all ARL libraries receiving surveys-64 of 119 libraries. When the 64 libraries are counted among responding libraries, the percentage becomes much higher- $77.1 \%$ of the respondents to the survey. Original subject analysis and nonfiction classification are 
sometimes done by paraprofessionals in nearly half of all ARL libraries, a clear sign of the trend given that these two activities have traditionally been assigned exclusively to professionals. Original cataloging responsibilities alone are clearly no longer the distinguishing characteristic between professional and paraprofessional cataloging work.

The respondents to this survey expressed many valid concerns with increased paraprofessional involvement in original cataloging. These include paraprofessionals' lack of the theoretical background that is traditionally obtained by librarians in a graduate degree program, possible lesser commitment to the profession, extensive training time required, and also the issue of equity for the paraprofessionals who do advanced work.

The changes identified by this survey have far-reaching effects on cataloging departments, but this trend has implications for the profession as well because cataloging and technical services departments have often led the way in employing paraprofessionals in work previously considered professional. The trend will no doubt continue as economic pressures require that libraries become ever more cost-effective, but the desire to do more with less must be weighed against the need for appropriate compensation and recognition for paraprofessionals as they learn new skills and perform new tasks.

The challenge presented to librarians now is to define clearly these new roles for both professionals and paraprofessionals, continuing the groundwork laid by Veaner (1982), Bishoff (1987), Younger (1991), and Rider (1996). A survey among both professionals and paraprofessionals of current perceptions of and satisfaction with their roles might prove enlightening. Comparison with other professions that employ substantial numbers of paraprofessionals could offer some guidance in creating realistic definitions.

More research is also needed to examine the extent to which the profession is maturing (Nettlefold 1989) or its most professional functions are being deskilled (Harris 1992). These contrasting sociological perspectives on our work offer re- spectively positive and negative views of the increasing paraprofessional involvement in progressively more skilled cataloging activities. Is one or the other more correct? At the same time, Veaner, Bishoff, Younger, and Rider continue to see important roles for professionals in bibliographic access and technical services.

Despite the concerns raised by respondents to this survey, paraprofessionals continue to be more involved in all facets of original cataloging over time. Many heads of cataloging in ARL libraries have clearly discovered that, with training and supervision, paraprofessional catalogers can do a good job on the time-consuming work of original cataloging.

\section{WORKs CiTED}

Benaud, Clair-Lise. 1992. The academic paraprofessional cataloger: Underappreciated? Cataloging \& classification quarterly 15, no. 3: 81-92.

Benemann, William E. 1993. The cathedral factor: Excellence and the motivation of cataloging staff. Technical services quarterly 10 , no. $3: 17-25$.

Bishoff, Lizbeth J. 1987. Who says we don't need catalogers? American libraries 18 : 694-96.

Braden, Sally, John D. Hall, and Helen H. Britton. 1980. Utilization of personnel and bibliographic resources for cataloging by OCLC participating libraries. Library resources \& technical services 24: 135-54.

Conturbia, Sandra da. 1992. Who catalogs foreign-language materials? A survey of ARL libraries. Technical services quarterly 10 , no. 1: 15-26.

Dyckman, A. Ann. 1992. Library assistants in the year 2000 . Journal of library administration 17, no. 1: 77-90.

Eskoz, Patricia A. 1990. The catalog librarian-change or status quo? Results of a survey of academic libraries. Library resources b technical services 34: 380-92.

Estabrook, Leigh, Lisa Mason, and Sara Suelflow, 1993. Managing the work of support staff. Library trends 41: 231-49.

Foster, Donald L. 1987. Managing the catalog department. Metuchen, N.J.: Scarecrow.

Harris, Roma. 1992. Information technology and the de-skilling of librarians; or, the erosion of a woman's profession. Computers in libraries 12, no. 1: 8-16. 
Nettlefold, Brian A. 1989. Paraprofessionalism in librarianship. International library review 21 , no. 4: 519-31.

Oberg, Larry R. 1994. Library staffing in an age of change. Paper presented at the 113th ALA Annual Conference, Miami Beach, Fla.

- 1995. Library staffing in an age of change. Paper presented at the 7th ACRL National Conference, Pittsburgh, Pa.

Oberg, Larry R, and others. 1992. The role, status, and working conditions of paraprofessionals: A national survey of academic libraries. College \& research libraries 53 : 215-38.

Paiste, Marsha Starr, and Jane Mullins. 1990. Job enrichment for catalogers. College \& research libraries news 51, no. 1: 4-8.
Rider, Mary. 1996. Developing new roles for paraprofessionals in cataloging. Journal of academic librarianship 22, no. I: 26-32.

Veaner, Allen B. 1982. Continuity or discontinuity: A persistent personnel issue in academic librarianship. In Advances in $l i$ brary administration and organization, vol. 1, ed. G. B. McCabe, B. Kreissman, and W. C. Jackson. Greenwich, Conn.: JAI Pr.

Williams, Delmus E. 1991. Managing technical services in the 1990's: The ruminations of a library director. Journal of library administration 15, no. 1/2: 25-41.

Younger, Jennifer A. 1991. The role of librarians in bibliographic access services in the 1990 s. Journal of library administration 15 , no. 1/2: 125-50. 